\title{
Peptidoglycan Increases Firm Adhesion of Monocytes under Flow Conditions and Primes Monocyte Chemotaxis
}

\author{
Manon M. Oude Nijhuis ${ }^{a, b}$ Gerard Pasterkamp ${ }^{a} \quad$ Nienke I. Sluis ${ }^{a}$ \\ Dominique P.V. de Kleijna, b Jon D. Laman ${ }^{c}$ Laurien H. Ulfman ${ }^{d}$ \\ ${ }^{a}$ Experimental Cardiology Laboratory, University Medical Center Utrecht, Utrecht, ${ }^{\mathrm{b}}$ Interuniversity Cardiology

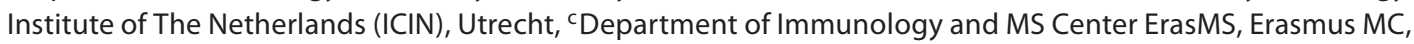 \\ Rotterdam, and ${ }^{\mathrm{d}}$ Department of Pulmonary Diseases, University Medical Center Utrecht, Utrecht, The Netherlands
}

\section{Key Words}

Leukocytes · Infection/inflammation • Immunology

Atherosclerosis $\cdot$ Receptors

\begin{abstract}
The Toll-like receptor (TLR) 2/nucleotide-binding oligomerization domain ligand peptidoglycan (PG) has been shown to be present in macrophage-rich regions within atherosclerotic lesions, and stimulation of TLR2 promotes atherosclerotic plaque and intima formation in in vivo mouse models. We determined the effect of a PG preparation and $\mathrm{Pam}_{3} \mathrm{Cys}_{-}$ $\mathrm{SK}_{4}$, a synthetic TLR2 activator, on (1) adhesion molecule expression by flow cytometry; (2) monocyte adhesion under flow conditions, and (3) monocyte migration. The total adhesion (rolling and firm adhesion) of the PG-preparationstimulated monocytes to $L$ cells, constitutively expressing ICAM-1 (intercellular adhesion molecule-1) and E-selectin, was decreased. This was most likely due to the L-selectin shedding, since monocyte incubation with a blocking L-selectin antibody resulted in a comparable number of adherent monocytes as PG-stimulated cells. The PG preparation induced an increased percentage of firmly adherent, polarized cells and a $\beta_{2}$-integrin-dependent binding to ICAM-1coated beads. Interestingly, the PG preparation induced a priming of the monocytes for increased migration towards the chemoattractant C5a which was TLR2 and $\beta_{2}$-integrin
\end{abstract}

dependent. $\mathrm{Pam}_{3} \mathrm{Cys}_{\mathrm{S}} \mathrm{SK}_{4}$ gave comparable results to the PG preparation in all assays tested. This study demonstrates that PG activation of monocytes results in an increase in adhesive and migratory capacities of these cells. This might be a mechanism by which PG promotes atherosclerotic disease in vivo.

Copyright $\odot 2007$ S. Karger AG, Basel

\section{Introduction}

One of the first steps in the series of events underlying atherosclerotic plaque formation is the recruitment of monocytes to the site of vascular damage, with subsequent uptake of oxidized lipid particles [1]. Atherogenic lesions have been observed to arise at regions of the vessel wall exhibiting endothelial activation. The adhesion of circulating monocytes to the activated endothelium is an important first event in the inflammatory response. As with all leukocytes, monocyte adhesion to activated endothelial cells is a multistep process [2]. First, L-selectin (CD62L) and the P-selectin glycoprotein ligand-1 (CD162) expressed on monocytes and E-selectin (CD62E) and Pselectin (CD62P) expressed on activated endothelial cells mediate the initial tethering and rolling interactions of these cells. When a rolling monocyte encounters chemokines presented by the activated endothelial cells, integ-

\section{KARGER}

Fax +4161306 1234 E-Mail karger@karger.ch www.karger.com (c) 2007 S. Karger AG, Basel $1018-1172 / 07 / 0443-0214 \$ 23.50 / 0$

Accessible online at: www.karger.com/jvr
Dr. Gerard Pasterkamp

Experimental Cardiology Laboratory, Heart Lung Center Utrecht

University Medical Center Utrecht, Room G02.523, Heidelberglaan 100

NL-3584 CX Utrecht (The Netherlands)

Tel. +31 30250 7155, Fax +31 30252 2693, E-Mail g.pasterkamp@umcutrecht.nl 
rins are activated, a process called inside-out signaling [3]. Not only chemokines, but also other stimuli like growth factors, cytokines, and bacterial-derived products such as lipopolysaccharide (LPS), a Toll-like receptor (TLR) 4 ligand [4], and lipoteichoic acid (LTA), a TLR2 ligand [5], are able to activate integrins on leukocytes. However, these stimuli act much more slowly (minutes) than chemokines (seconds) in integrin activation. Activated $\beta_{2}$-integrins and $\alpha_{4}$-integrins on the monocyte ensure firm adhesion by binding to intercellular adhesion molecule-1 (ICAM-1/CD54) and vascular cell adhesion molecule-1 (VCAM-1/CD106) on the activated endothelium, respectively $[2,6]$. Finally, the cells spread and migrate into the site of inflammation, where in the case of monocyte migration to the atherosclerotic plaque they develop into large lipid-laden macrophages [1].

Monocytes are part of the innate immune system that provides a first line of defense against invading pathogens. This response is initiated by host pattern recognition receptors [7]. The most widely studied class of pattern recognition receptors are the TLRs. Ten members of the TLR family have been described, and all recognize specific microbial agents, also known as pathogen-associated molecular patterns [7]. The latter include, among others, LPS, LTA, peptidoglycan (PG), and flagellin. TLRs are transmembrane proteins that have been shown to initiate signaling cascades that ultimately regulate the immune response via nuclear factor kappa B. Of the ten members of the TLR-family, the expression of TLR1, TLR2, and TLR4 is markedly enhanced in human atherosclerotic plaques [8]. Recently, we observed that TLR4 [9] and TLR2 [10] ligation accelerates neointima formation in arteries of mice. In addition, we previously observed that PG, a bacterial TLR2/nucleotide-binding oligomerization domain (NOD) ligand, is prevalent in atherosclerotic lesions with an inflammatory unstable phenotype. The presence of PG was mainly observed in macrophagerich atheromatous regions [11]. PG is the major constituent of Gram-positive bacteria and is known to induce the production of proinflammatory cytokines. In a clinical study, we demonstrated a significant relation between PG-specific IgM antibody levels and carotid intima-media thickness [12].

The mechanisms by which TLR2 ligation could enhance initiation or progression of atherosclerotic plaque formation are unknown. Considering the aforementioned relation of PG staining with vulnerable inflammatory plaque characteristics, we hypothesized that stimulation of monocytes by PG affects the adhesive and migratory properties of these cells, contributing to lesion growth. Some controversy exists on whether PG is a genuine TLR2 ligand, in addition to its uncontested NOD engagement $[13,14]$. Therefore, we systematically compared the activity of our Staphylococcus aureus PG preparation [15] with the commercial synthetic TLR2 ligand, $\mathrm{Pam}_{3} \mathrm{Cys}-\mathrm{SK}_{4}$. In the present study, we investigated the effects of the PG preparation and $\mathrm{Pam}_{3} \mathrm{Cys}_{\mathrm{S}} \mathrm{SK}_{4}$ on adhesion molecule expression and adhesion to E-selectin- and ICAM-1-expressing $L$ cells in an in vitro flow chamber model and on migration of primary human monocytes.

\section{Materials and Methods}

\section{Antibodies}

mAbs IB4 and DREG56 and control antibody W6/32 (antiHLA-A, anti-HLA-B, anti-HLA-C) were isolated from the supernatant of hybridoma obtained from the American Type Culture Collection (Rockville, Md., USA). BBA2 (clone 5D11) was purchased from R \& D Systems (Minneapolis, Minn., USA), and ENA2 was kindly provided by Dr. Buurman (University of Limburg, Maastricht, The Netherlands). TLR2-blocking antibody (clone TLR2.1) was obtained from eBioscience (San Diego, Calif., USA). Anti-CD18-FITC, anti-CD11b-PE, and anti-CD62L-FITC antibodies were purchased from DAKO (Glostrup, Denmark). The MAbs were incubated with monocytes $\left(4 \times 10^{6}\right.$ cells $\left./ \mathrm{ml}\right)$ or with confluent $\mathrm{L}$ cell layers on coverslips at $10 \mu \mathrm{g} / \mathrm{ml}$ during 15 min before the experiments. The cell suspensions were diluted once with HEPES incubation buffer (final concentration $5 \mu \mathrm{g} / \mathrm{ml}$ $\mathrm{mAb}$ at $2 \times 10^{6}$ cells $/ \mathrm{ml}$ ). HEPES incubation buffer contained 20 mM HEPES, $132 \mathrm{~mm} \mathrm{NaCl}, 6 \mathrm{mM} \mathrm{KCl}, 1 \mathrm{mM} \mathrm{MgSO}_{4}, 1.2 \mathrm{~mm}$ $\mathrm{KH}_{2} \mathrm{PO}_{4}$, supplemented with $5 \mathrm{mM}$ glucose, $1.0 \mathrm{mM} \mathrm{CaCl}_{2}$, and $0.5 \%(\mathrm{w} / \mathrm{v})$ human serum albumin.

\section{TLR2 Ligands}

Since commercial PG preparations are routinely contaminated with LPS (and vice versa), PG was isolated from S. aureus using a special methodology, as described previously [16], and kindly provided by Prof. Dr. Zähringer (Leibniz Center for Medicine and Biosciences, Borstel, Germany). This isolated PG is a crude PG preparation containing lipopeptides that show TLR2 activity as well, but most likely not related to LTA. Importantly, the preparation was rigorously checked for LPS contamination which was below the detection limit ( $15 \mathrm{pg} / \mathrm{mg}$ ). We compared the activity of our PG preparation with that of the commercial synthetic TLR2 ligand, $\mathrm{Pam}_{3}$ Cys-SK $\mathrm{SK}_{4}$ (Calbiochem-Novabiochem International, Cambridge, Mass., USA). This is a cell-permeable, watersoluble cationic lipohexapeptide analog of the immunologically active $\mathrm{N}$-terminal portion of bacterial lipoprotein known for its ability to activate monocytes and macrophages [17]. Monocytes $\left(2 \times 10^{6}\right.$ cells $\left./ \mathrm{ml}\right)$ were stimulated with the PG preparation $\left(3 \mu \mathrm{g} / 1 \times 10^{6}\right.$ cells $)$ and $\mathrm{Pam}_{3} \mathrm{Cys} \mathrm{SK}_{4}\left(1 \mu \mathrm{g} / 1 \times 10^{6}\right.$ cells $)$ for 30 min at $37^{\circ} \mathrm{C}$ unless stated otherwise.

\section{Isolation of Monocytes}

Blood, anticoagulated with $0.4 \%$ trisodium citrate $(\mathrm{pH} 7.4)$, was obtained from healthy volunteers from the University Medical Centre Utrecht, The Netherlands. Mononuclear cells were 
separated from granulocytes and red blood cells by centrifugation over isotonic $1.077 \mathrm{~g} / \mathrm{ml}$ Ficoll-Paque (Pharmacia, Uppsala, Sweden). Monocytes were further purified from peripheral blood mononuclear cells by depletion of nonmonocytes (negative selection) via magnetic cell sorting using a human monocyte isolation kit (Miltenyi Biotec, Bergisch Gladbach, Germany). After isolation, the cells were resuspended in HEPES incubation buffer $(4 \times$ $10^{6}$ cells $/ \mathrm{ml}$ ) and kept on ice.

\section{Flow Cytometry}

Flow cytometric analysis was carried out as described before [18]. In short, the monocytes were incubated with either the PG preparation or $\mathrm{Pam}_{3} \mathrm{Cys}-\mathrm{SK}_{4}$ for $5-60 \mathrm{~min}$ at $37^{\circ} \mathrm{C}$. After washing with cold phosphate-buffered saline, antibodies against $\alpha_{\mathrm{m}} \beta_{2}$-integrins ( $\alpha$ CD11b-PE and $\alpha$ CD18-FITC) and L-selectin $(\alpha \mathrm{CD} 62 \mathrm{~L}$ FITC) were added to the cells and incubated in the dark for $45 \mathrm{~min}$ at $4^{\circ} \mathrm{C}$. After washing the cells, fluorescence was quantified for 10,000 cells with a FACSvantage flow cytometer (Becton Dickinson Immunocytometry Systems, Mountain View, Calif., USA). Polymixin B sulfate (15 $\mu \mathrm{g} / \mathrm{ml}$; Calbiochem, San Diego, Calif., USA) was used in some samples and showed no difference in outcome as compared with nontreated samples, excluding the possibility of LPS contamination in our PG batch.

\section{Cells}

L cells were kindly provided by Dr. W. Smith (Baylor College of Medicine, Houston, Tex., USA). These L cells transfected with ICAM-1 and E-selectin [19] were cultured in RPMI 1640 medium supplemented with glutamine and neomycin. L cells coated on Thermanox coverslips $(18 \times 18 \mathrm{~mm}$, confluent cell layer $)$ were used in perfusion assays.

\section{Monocyte Perfusion and Evaluation}

Perfusions under steady flow were performed in a modified transparent parallel-plate perfusion chamber, as described by van Zanten et al. [20]. In vitro flow chamber experiments were performed as described previously [21]. In short, monocytes in suspension $\left(2 \times 10^{6}\right.$ cells $/ \mathrm{ml}$ in HEPES incubation buffer, preincubated with the PG preparation, $\mathrm{Pam}_{3} \mathrm{Cys}-\mathrm{SK}_{4}$, or control $\mathrm{mAb}$ $\mathrm{W} 6 / 32$ for $30 \mathrm{~min}$ at $37^{\circ} \mathrm{C}$ ) were aspirated from a reservoir through the perfusion chamber (for 5 min at shear stresses of 0.8 and 1.6 $\mathrm{dyn} / \mathrm{cm}^{2}$ ) and recorded on videotape. Video images were evaluated for the number of adherent cells, cluster index, and percentage of rolling cells, using dedicated image analysis routines (Optimas 6.1 image analysis software; Media Cybernetics, Silver Spring, Md., USA).

\section{Fluorescent Bead Adhesion Assay}

The functionality of $\beta_{2}$-integrins was measured using ICAM1 -coated fluorescent microbeads. TransFluorSpheres (488/645 $\mathrm{nm}$ by $1.0 \mu \mathrm{m}$; Molecular Probes, Eugene Oreg., USA) were coated with adhesion ligands, and the fluorescent bead adhesion assay was performed according to the method of Geijtenbeek et al. [22]. In short, monocytes were resuspended in HEPES incubation buffer. Fifty thousand cells were preincubated with control antiHLA-ABC (W6/32) $\mathrm{mAb}$ or with anti- $\beta_{2}$-integrin-blocking $\mathrm{mAb}$ IB4 $(10 \mu \mathrm{g} / \mathrm{ml})$ and $0.6 \mu \mathrm{g} / 100 \mu \mathrm{l}$ PG preparation or $0.2 \mu \mathrm{g} / 100$ $\mu \mathrm{l} \mathrm{Pam}{ }_{3} \mathrm{Cys}_{-} \mathrm{SK}_{4}$ for $30 \mathrm{~min}$ at $37^{\circ} \mathrm{C}$. The ligand-coated beads $(40$ beads/cell) were washed twice and added together with the recombinant human complement factor $\mathrm{C} 5 \mathrm{a}\left(10^{-8} \mathrm{M}\right.$; Sigma Chem- ical, St. Louis, Mo., USA) in a 96-well V-shaped-bottom plate. Next, the preincubated monocytes were added and incubated for $30 \mathrm{~min}$ at $37^{\circ} \mathrm{C}$. The cells were washed and resuspended in HEPES incubation buffer $\left(4^{\circ} \mathrm{C}\right)$ and kept on ice until measurement. Binding of the fluorescent beads to the monocytes was determined by flow cytometry using the FACSvantage and is depicted as percentage of monocytes positive for ICAM-1-coated beads.

\section{Boyden Chamber Migration Assay}

The monocyte migration was measured in the modified Boyden chamber assay, as described [23]. Briefly, the monocytes $(1 \times$ $10^{6}$ cells $/ \mathrm{ml}$ ) were preincubated with control $\mathrm{mAb}(\mathrm{W} 6 / 32), \beta_{2}-$ integrin-blocking $\mathrm{mAb}$ IB4, or a TLR2-blocking $\mathrm{mAb}$ for $10 \mathrm{~min}$ at $37^{\circ} \mathrm{C}$, followed by incubation with the PG preparation, $\mathrm{Pam}_{3} \mathrm{Cys}_{-} \mathrm{SK}_{4}$, or control $\mathrm{mAb} \mathrm{W} 6 / 32$ for $30 \mathrm{~min}$ at $37^{\circ} \mathrm{C}$. The chemoattractant $\mathrm{C} 5 \mathrm{a}$ (at physiologically relevant $10^{-8} \mathrm{M}$ ) and control HEPES incubation buffer were given into the bottom chamber and the monocytes into the upper chamber. The monocytes were incubated for $3 \mathrm{~h}$ in the Boyden chamber at $37^{\circ} \mathrm{C}$. Filters were fixed in $80 \% \mathrm{EtOH} / 20 \% \mathrm{BuOH}$, stained with Weigert solution, and embedded in malinol. Analysis of the filters was done by an image analysis system (Quantimet 570 C; Leica Microsystems, Wetzlar, Germany) and an automated microscope to score the number of cells at 15 intervals of $10 \mu \mathrm{m}$ in the Z-direction of the filters. The results are expressed as the mean migrated distance in micrometers, excluding cells with migration 0 .

\section{Statistics}

The results are expressed as mean \pm SEM. Statistical analysis of the data was performed using Student's t test. $\mathrm{p}<0.05$ was considered statistically significant.

\section{Results}

\section{The PG Preparation Induces an Increased $\alpha_{m} \beta_{2}$-Integrin Expression on and L-Selectin Shedding from Monocytes \\ To investigate whether PG preparation and $\mathrm{Pam}_{3} \mathrm{Cys}-$} $\mathrm{SK}_{4}$ affect the expression levels of adhesion molecules on monocytes, the cells were incubated with these compounds at $37^{\circ} \mathrm{C}$ for $5-60 \mathrm{~min}$. The expression of adhesion molecules CD11b, CD18, and CD62L was measured by flow cytometry (table 1). PG preparation as well as $\mathrm{Pam}_{3}$ Cys-SK $\mathrm{S}_{4}$ activation resulted in a time-dependent increase in the expression of the $\alpha_{\mathrm{m}} \beta_{2}$-integrins CD11b and $\mathrm{CD} 18$, with a maximal expression at $30 \mathrm{~min}$. The CD62L expression decreased upon stimulation with PG preparation and $\mathrm{Pam}_{3}$ Cys-SK 4 , with a maximal inhibition 30 min after incubation. The pattern of adhesion molecule expression on the PG-preparation-stimulated monocytes was comparable to the pattern of $\mathrm{Pam}_{3} \mathrm{Cys}_{\text {-SK }}$-stimulated cells, suggesting that stimulation with both ligands resulted in an increased functionality state of the adhesion molecules. 
Fig. 1. PG preparation stimulation results in decreased total adhesion, but increased firm adhesion of monocytes to L cell layers. Monocytes $\left(2 \times 10^{6}\right.$ cells $/ \mathrm{ml}, 30 \mathrm{~min}$, $37^{\circ} \mathrm{C}$ ) were perfused over confluent $\mathrm{L}$ cell layers at a shear stress of $0.8 \mathrm{dyn} / \mathrm{cm}^{2}$. Total number of adherent cells (rolling and firmly adherent cells) (A) and percentage of rolling cells (B) after blocking of Lselectin (DREG56) on monocytes, Eselectin (BBA2) on L cells, or blocking both $(n=3)$. Total number of adherent cells (C) and percentage of firm adhesion (D) of control, PG-preparation-stimulated $\left(3 \mu \mathrm{g} / 1 \times 10^{6}\right.$ cells), or $\mathrm{Pam}_{3} \mathrm{Cys}-\mathrm{SK}_{4}$ stimulated $\left(1 \mu \mathrm{g} / 1 \times 10^{6}\right.$ cells $)$ monocytes and monocytes incubated with the L-selectin-blocking antibody DREG56 to confluent $L$ cell layers $(n=10-16)$. Results are expressed as mean \pm SEM. ${ }^{*} \mathrm{p}<0.05$.

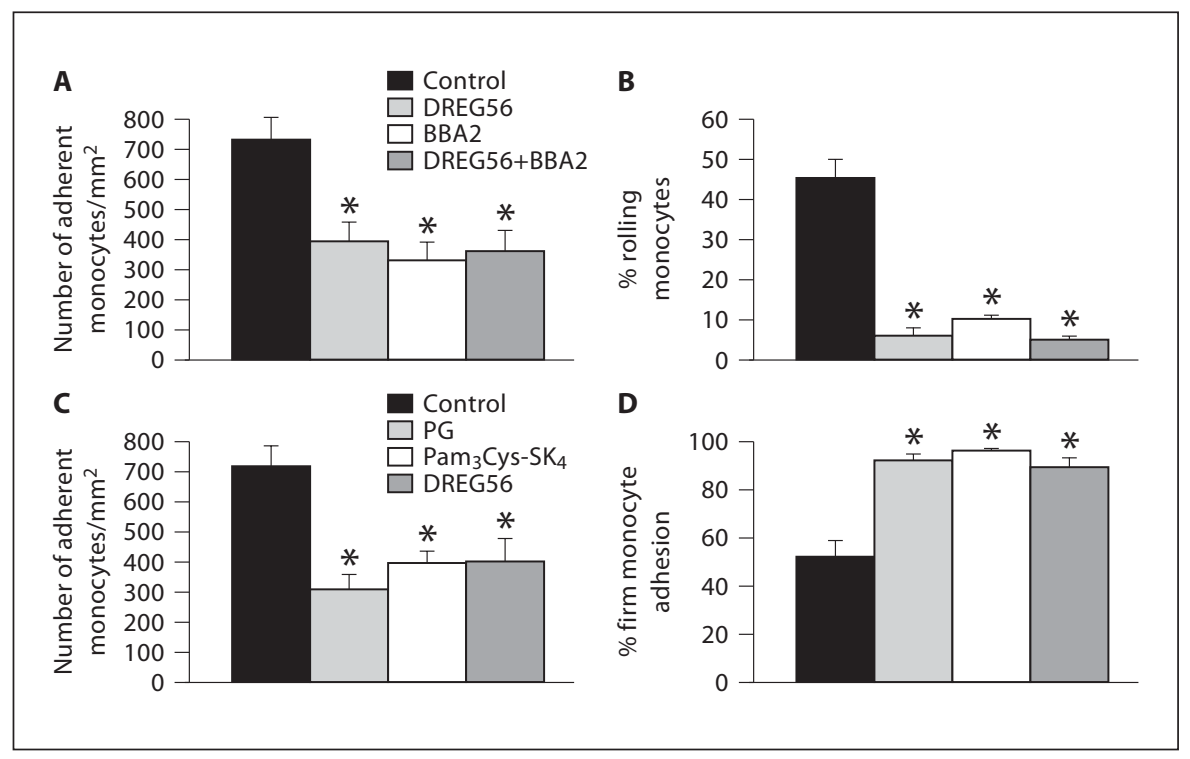

Table 1. Expression of $\beta_{2}$-integrins (CD18 and CD11b) and L-selectin (CD62L) on the monocyte surface after PG preparation and $\mathrm{Pam}_{3} \mathrm{Cys}-\mathrm{SK}_{4}$ stimulation

\begin{tabular}{|c|c|c|c|c|c|c|c|c|c|}
\hline \multirow{2}{*}{$\begin{array}{l}\text { Time } \\
\text { min }\end{array}$} & \multicolumn{3}{|l|}{ CD18 } & \multicolumn{3}{|l|}{ CD11b } & \multicolumn{3}{|l|}{ CD62L } \\
\hline & control & $\begin{array}{l}\text { PG } \\
\text { preparation }\end{array}$ & $\mathrm{Pam}_{3}$ Cys-K 4 & control & $\begin{array}{l}\text { PG } \\
\text { preparation }\end{array}$ & $\mathrm{Pam}_{3}$ Cys-SK 4 & control & $\begin{array}{l}\text { PG } \\
\text { preparation }\end{array}$ & $\mathrm{Pam}_{3}$ Cys-SK ${ }_{4}$ \\
\hline 0 & $384 \pm 12$ & $384 \pm 12$ & $384 \pm 12$ & $419 \pm 85$ & $419 \pm 85$ & $419 \pm 85$ & $224 \pm 21$ & $224 \pm 21$ & $224 \pm 21$ \\
\hline 5 & $398 \pm 24$ & $419 \pm 23$ & $446 \pm 39$ & $494 \pm 29$ & $593 \pm 33$ & $830 \pm 66$ & $183 \pm 21$ & $147 \pm 21$ & $122 \pm 11$ \\
\hline 15 & $452 \pm 23$ & $566 \pm 48^{*}$ & $631 \pm 10^{*}$ & $591 \pm 97$ & $926 \pm 20^{*}$ & $1,167 \pm 179^{*}$ & $144 \pm 18$ & $45 \pm 4^{*}$ & $22 \pm 4^{*}$ \\
\hline 30 & $484 \pm 21$ & $693 \pm 73^{*}$ & $680 \pm 42^{*}$ & $772 \pm 38$ & $1,467 \pm 90^{*}$ & $1,551 \pm 23^{*}$ & $144 \pm 37$ & $30 \pm 3^{*}$ & $27 \pm 5^{*}$ \\
\hline 60 & $521 \pm 3$ & $657 \pm 37^{*}$ & $661 \pm 34^{*}$ & $929 \pm 55$ & $1,551 \pm 14^{*}$ & $1,568 \pm 30^{*}$ & $134 \pm 26$ & $27 \pm 6^{*}$ & $26 \pm 3^{*}$ \\
\hline
\end{tabular}

PG preparation stimulation induces L-selectin (CD62L) shedding from the monocyte surface and increases $\alpha_{\mathrm{m}} \beta_{2}$-integrin (CD18 and CD11b) expression.

The expression of CD18, CD11b, and CD62L on monocytes was measured after 5-60 min of PG preparation $\left(3 \mu \mathrm{g} / 1 \times 10^{6} \mathrm{cells}\right)$ or Pam ${ }_{3}$ Cys-SK $\mathrm{SK}_{4}$ stimulation $\left(1 \mu \mathrm{g} / 1 \times 10^{6}\right.$ cells $)$ at $37^{\circ} \mathrm{C}\left(2 \times 10^{6}\right.$ cells $\left./ \mathrm{ml}\right)$. After stimulation with both ligands, monocytes were stained for the adhesion molecules, washed, and measured by flow cytometry $(n=7)$.

Data are expressed as mean fluorescence intensity \pm SEM.

${ }^{*} \mathrm{p}<0.05$ compared to controls.

The PG Preparation Leads to a Decrease in Total Adhesion but an Increase in Firm Adhesion and Polarization of Monocytes under Flow Conditions

The observed L-selectin shedding by PG stimulation suggested that this would affect monocyte recruitment to endothelial cells. L cells, constitutively expressing E-selectin and ICAM-1, were used to test this hypothesis, since this surface is known to support L-selectin-mediated rolling of neutrophils [24]. Indeed, figure 1A shows that blocking L-selectin (DREG56) on monocytes or Eselectin (BBA2) on L cells or blocking both resulted in a decrease in total adhesion as compared with control mAb-treated cells $(389 \pm 69,327 \pm 63$, and $358 \pm 71$ cells $/ \mathrm{mm}^{2}$, respectively, versus $729 \pm 74$ cells $/ \mathrm{mm}^{2} ; \mathrm{p}=$ $0.01, p=0.006$, and $p=0.01$, respectively). Also, a significant decrease in the percentage of rolling cells was seen when L-selectin, E-selectin, or both were inhibited (fig. 1B). 
When the monocytes were prestimulated with the PG preparation or $\mathrm{Pam}_{3} \mathrm{Cys}-\mathrm{SK}_{4}$ for $30 \mathrm{~min}$ at $37^{\circ} \mathrm{C}$, the total number of adherent cells to the $\mathrm{L}$ cell layer decreased to similar levels as DREG56-treated monocytes: PG, $309 \pm$ 50 cells $/ \mathrm{mm}^{2}, \mathrm{p}<0.001$ vs. controls; $\mathrm{Pam}_{3}$ Cys-SK 4,394 \pm 44 cells $/ \mathrm{mm}^{2}, \mathrm{p}=0.003$ vs. controls, and DREG56, 402 \pm 78 cells $/ \mathrm{mm}^{2}, \mathrm{p}=0.004$ vs. controls $(718 \pm 71$ cells/ $\mathrm{mm}^{2}$; fig. 1C).

This suggests that PG-preparation-induced and $\mathrm{Pam}_{3} \mathrm{Cys}-\mathrm{SK}_{4}$-induced L-selectin shedding is responsible for the decrease in total adhesion. Furthermore, the percentage of firm adhesion of monocytes to the $\mathrm{L}$ cell layer of PG-preparation-treated or $\mathrm{Pam}_{3} \mathrm{Cys}_{-} \mathrm{SK}_{4}$-treated cells as compared with control monocytes was greatly increased (92 \pm 3 and $96 \pm 1 \%$, respectively, vs. $52 \pm 7 \%$; $p<0.001$ and $p=0.004$, respectively; fig. 1D). This was comparable to the DREG56-treated monocytes (89 \pm $4 \%, \mathrm{p}=0.01$ vs. controls). Experiments performed at a shear stress of $1.6 \mathrm{dyn} / \mathrm{cm}^{2}$ gave comparable results.

However, a clear difference between the DREG56treated and the PG-preparation-treated cells was the appearance of the cells. Unstimulated control mAb-treated monocytes appeared as round, bright-white-centered cells (fig. 2A), indicating that these cells were not activated. Similarly, the DREG56-treated cells that were firmly attached also had a rounded morphology (fig. 2D). In contrast, the PG-preparation-stimulated and $\mathrm{Pam}_{3} \mathrm{Cys}$ $\mathrm{SK}_{4}$-stimulated cells polarized immediately after attachment to the endothelium (fig. 2B and C for PG-stimulated and $\mathrm{Pam}_{3} \mathrm{Cys}-\mathrm{SK}_{4}$-stimulated cells, respectively). This suggests that TLR2 ligation in addition to its effect on functional L-selectin shedding also induces activation of the cells, resulting in cell spreading. This prompted us to further determine the activation of integrins and the migration capacities of the PG-preparation-ligated and $\mathrm{Pam}_{3} \mathrm{Cys}-\mathrm{SK}_{4}$-ligated monocytes.

\section{The PG-Preparation-Induced Inside-Out Signaling}

Leads to Activation of $\beta_{2}$-Integrins

It has been well documented that not the increased expression levels of $\beta_{2}$-integrins but instead the activation of the integrins via inside-out signaling leads to increased adhesion of monocytes to ICAM-1. Therefore, we determined the binding of monocytes to ICAM-1-coated fluorescent beads using a flow-cytometry-based adhesion assay. Monocytes were preincubated with a control $\mathrm{mAb}$ or a blocking $\beta_{2}$-integrin $\mathrm{mAb}$ and then stimulated with PG preparation or $\mathrm{Pam}_{3} \mathrm{Cys}-\mathrm{SK}_{4}$. Stimulation by the PG preparation or $\mathrm{Pam}_{3}$ Cys-SK 4 significantly increased binding of monocytes to the ICAM-1-coated beads as compared
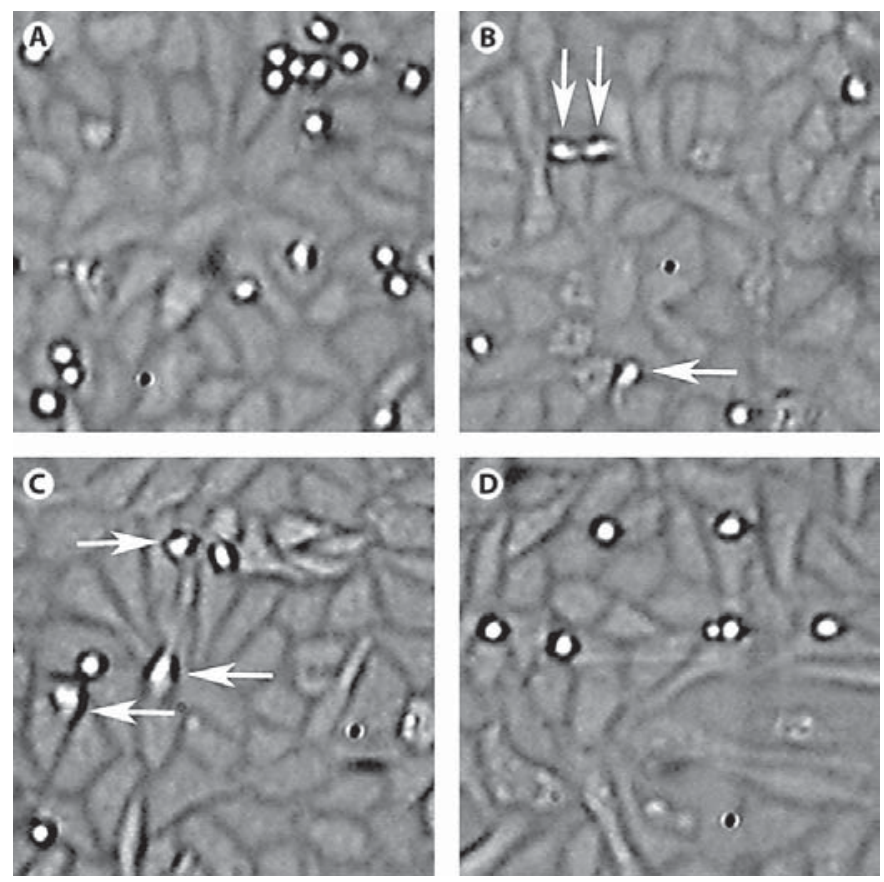

Fig. 2. Spreading of monocytes on endothelial cells under flow is induced by PG preparation stimulation. Video microscopy of adherent monocytes on $\mathrm{L}$ cells under flow conditions. The monocytes were untreated (A), pretreated with the PG preparation (B) or Pam $_{3}$ Cys-SK 4 (C), or incubated with DREG56, an L-selectinblocking antibody (D) and perfused over the L cells at a shear stress of $0.8 \mathrm{dyn} / \mathrm{cm}^{2}$. Images were recorded on video during $5 \mathrm{~min}$. The images depicted were taken after $3 \mathrm{~min}$ of monocyte perfusion. The firmly adhering control monocytes remained round, white-centered cells, whereas the PG-preparation-stimulated or Pam ${ }_{3} \mathrm{Cys}-\mathrm{SK}_{4}$-stimulated monocytes spread within a few moments (arrows indicate spreading cells), indicative of active migration. Once firmly adhered, the DREG56-incubated monocytes remained rounded.

with control monocytes ( $38 \pm 6$ and $37 \pm 3 \%$, respectively, vs. $18 \pm 3 \% ; \mathrm{p}=0.02$ and $\mathrm{p}=0.01$, respectively; fig. 3). Incubation of the monocytes with the $\beta_{2}$-integrinblocking mAb IB4 abrogated monocyte binding to the fluorescent beads, showing that the interaction is $\beta_{2}$-integrin specific (PG, $7.3 \pm 2.0 \%, \mathrm{p}=0.002$ vs. control $\mathrm{mAb}$; $\mathrm{Pam}_{3} \mathrm{Cys}_{-} \mathrm{SK}_{4}, 6.0 \pm 0.5 \%, \mathrm{p}=0.007$ vs. control $\mathrm{mAb}$, and controls, $4.5 \pm 0.7 \%, \mathrm{p}=0.002$ vs. control $\mathrm{mAb}$ ).

\section{TLR2-Dependent Priming of Monocytes by the PG \\ Preparation Results in Increased \\ $\beta_{2}$-Integrin-Dependent Migration towards C5a}

Activated integrins are a prerequisite for chemotaxis. Although chemokines can activate integrins, this does 


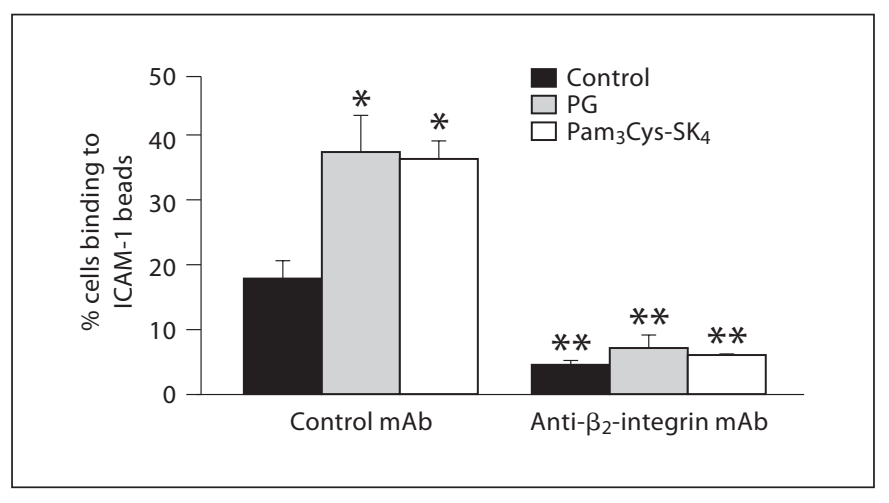

Fig. 3. PG preparation stimulation increases monocyte binding to ICAM-1-coated fluorescent beads. The percentage binding of the control and TLR2-stimulated monocytes to fluorescent ICAM-1coated beads, measured by flow cytometry, is shown. Monocytes $\left(2 \times 10^{6}\right.$ cells $\left./ \mathrm{ml}\right)$ were preincubated with a control $\mathrm{mAb}$ or a $\beta_{2^{-}}$ integrin-blocking $\mathrm{mAb}$ and were either not stimulated or stimulated with the PG preparation $\left(3 \mu \mathrm{g} / 1 \times 10^{6}\right.$ cells) or $\mathrm{Pam}_{3} \mathrm{Cys}-$ $\mathrm{SK}_{4}\left(1 \mu \mathrm{g} / 1 \times 10^{6}\right.$ cells $)$ for $30 \mathrm{~min}$ at $37^{\circ} \mathrm{C}$. Results are expressed as mean $\pm \operatorname{SEM}(\mathrm{n}=6) .{ }^{*} \mathrm{p}<0.05$ when compared to control monocytes; ${ }^{* *} \mathrm{p}<0.05$ when compared to control $\mathrm{mAb}$.

not always lead to optimal migration. Therefore, we tested whether PG preparation and $\mathrm{Pam}_{3} \mathrm{Cys}-\mathrm{SK}_{4}$ could prime the monocytes for enhanced migration towards C5a in a Boyden chamber assay. Indeed, the PG preparation or $\mathrm{Pam}_{3} \mathrm{Cys}-\mathrm{SK}_{4}$ greatly enhanced migration towards $\mathrm{C} 5 \mathrm{a}\left(10^{-8} \mathrm{M}\right)$ as compared with unstimulated cells: PG preparation $45 \pm 5 \mu \mathrm{m}$ versus unstimulated cells and $\mathrm{Pam}_{3} \mathrm{Cys}_{\mathrm{S}} \mathrm{SK}_{4} 61 \pm 9 \mu \mathrm{m}$ versus unstimulated cells with a migration of $24 \pm 3 \mu \mathrm{m} ; \mathrm{p}=0.01$ and $\mathrm{p}=0.02$, respectively (fig. 4A). A trend in increased chemotaxis of the control monocytes towards C5a compared to HEPES incubation buffer was observed ( $24 \pm 3$ vs. $18 \pm 3 \mu \mathrm{m})$. Moreover, chemotaxis of the monocytes stimulated with the PG preparation or $\mathrm{Pam}_{3} \mathrm{Cys}_{-} \mathrm{SK}_{4}$ towards C5a was significantly increased as compared wih HEPES incubation buffer (PG, $45 \pm 5$ vs. $19 \pm 3 \mu \mathrm{m}, \mathrm{p}=0.01 ; \mathrm{Pam}_{3} \mathrm{Cys}_{-\mathrm{SK}_{4}}$, $61 \pm 9$ vs. $23 \pm 4 \mu \mathrm{m}, \mathrm{p}=0.007)$

Since PG is known to bind to TLR2, but also contains minimal motifs that can bind to intracellular NOD receptors leading to cell activation [25], we determined whether the priming effect of our PG preparation was TLR 2 specific. Figure $4 \mathrm{~B}$ shows that incubation of monocytes with a blocking TLR2 mAb (PG, $25 \pm 3$ vs. $41 \pm$ $2 \mu \mathrm{m}, \mathrm{p}=0.004 ; \mathrm{Pam}_{3}$ Cys-SK $_{4}, 26 \pm 3$ vs. $43 \pm 6 \mu \mathrm{m}$, $\mathrm{p}=0.036$; anti-TLR2 $\mathrm{mAb}$ vs. control $\mathrm{mAb}$, respectively) or a blocking $\beta_{2}$-integrin $\mathrm{mAb}$ (PG, $18 \pm 2$ vs. $41 \pm$

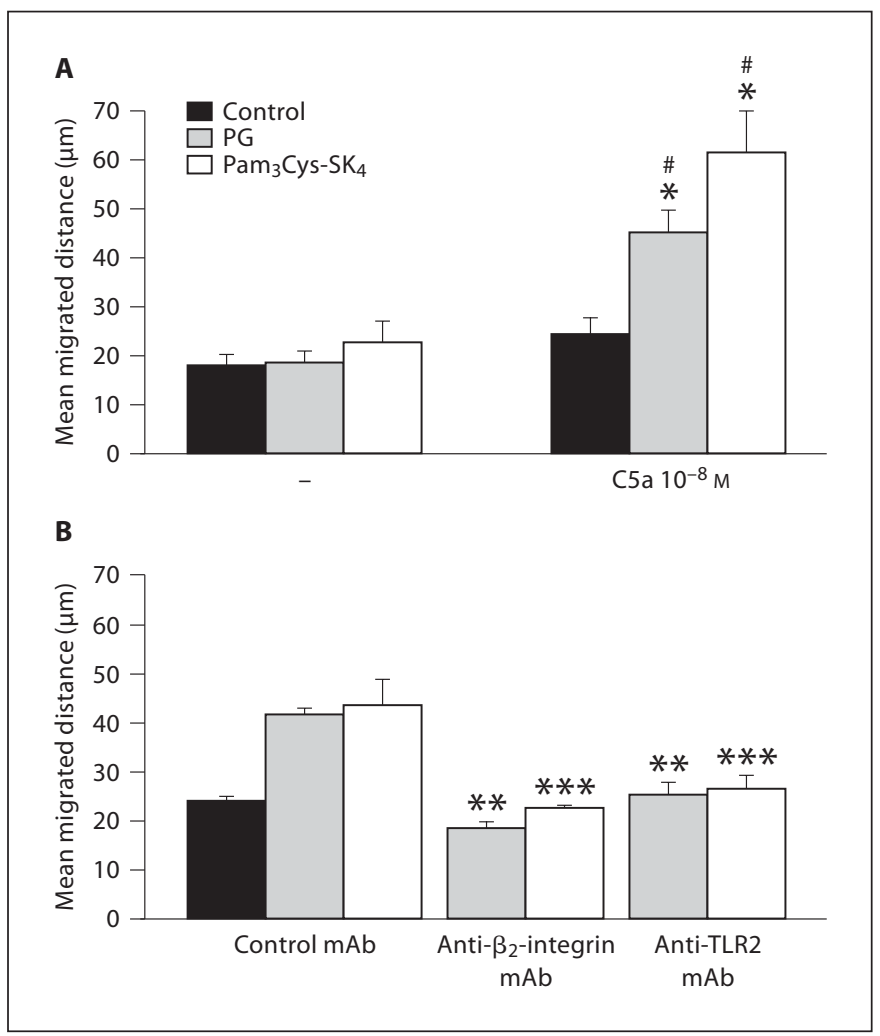

Fig. 4. The migratory capacity of monocytes is increased by TLR2 ligation. The mean migrated distance of the control and PG-preparation-stimulated or $\mathrm{Pam}_{3} \mathrm{Cys}-\mathrm{SK}_{4}$-stimulated monocytes towards HEPES incubation buffer and C5a $\left(10^{-8} \mathrm{M}\right)$ in a Boyden chamber assay is shown. A Mean migrated distance of monocytes $\left(2 \times 10^{6} \mathrm{cells} / \mathrm{ml}\right)$ that were left unstimulated or were stimulated with the PG preparation $\left(3 \mu \mathrm{g} / 1 \times 10^{6}\right.$ cells $)$ or $\mathrm{Pam}_{3} \mathrm{Cys}-\mathrm{SK}_{4}$ $\left(1 \mu \mathrm{g} / 1 \times 10^{6}\right.$ cells) for $30 \mathrm{~min}$ at $37^{\circ} \mathrm{C}$ and incubated for $3 \mathrm{~h}$ in the Boyden chamber $(n=7)$. B Migration of monocytes towards $\mathrm{C} 5 \mathrm{a}$. The monocytes were preincubated for $10 \mathrm{~min}$ at $37^{\circ} \mathrm{C}$ with control $\mathrm{mAb}$ (W6/32), a $\beta_{2}$-integrin-blocking $\mathrm{mAb}$, or a TLR2blocking $\mathrm{mAb}$, followed by incubation with $\mathrm{W} 6 / 32$, the PG preparation, or $\mathrm{Pam}_{3} \mathrm{Cys}-\mathrm{SK}_{4}$ for $30 \mathrm{~min}$ at $37^{\circ} \mathrm{C}$ and $3 \mathrm{~h}$ in the Boyden chamber $(n=4)$. Results are expressed as mean \pm SEM. ${ }^{*} \mathrm{p}<0.05$ compared to control monocytes; ${ }^{\#} \mathrm{p}<0.05$ compared to HEPES incubation buffer; ${ }^{* *} \mathrm{p}<0.05$ compared to PG-stimulated monocytes; ${ }^{* * *} \mathrm{p}<0.05$ compared to $\mathrm{Pam}_{3} \mathrm{Cys}-\mathrm{SK}_{4}$-stimulated monocytes.

$2 \mu \mathrm{m}, \mathrm{p}<0.001 ; \mathrm{Pam}_{3}$ Cys-SK $4,22 \pm 1$ vs. $43 \pm 6 \mu \mathrm{m}$, $\mathrm{p}=0.001$; anti $\beta_{2}$-integrin $\mathrm{mAb}$ vs. control $\mathrm{mAb}$, respectively) resulted in a significant decrease in the PG preparation-primed and $\mathrm{Pam}_{3} \mathrm{Cys}-\mathrm{SK}_{4}$-primed migration towards C5a. Thus, the PG preparation and $\mathrm{Pam}_{3}$ Cys$\mathrm{SK}_{4}$ effects are TLR2 specific and totally $\beta_{2}$-integrin dependent. 


\section{Discussion}

In this study, we examined the effects of our PG preparation and $\mathrm{Pam}_{3} \mathrm{Cys}-\mathrm{SK}_{4}$, which are known TLR2 ligands, on monocyte adhesion to E-selectin- and ICAM1-expressing $\mathrm{L}$ cells and on monocyte migration. We showed that PG preparation and $\mathrm{Pam}_{3} \mathrm{Cys}_{-} \mathrm{SK}_{4}$ stimulation lead to (1) shedding of L-selectin from the monocyte surface, resulting in a decrease in E-selectin-mediated rolling interactions under flow conditions; (2) an increased expression and function of $\beta_{2}$-integrins on monocytes, leading to polarization of the cells, and (3) priming of the monocytes, resulting in increased chemotaxis towards $\mathrm{C} 5 \mathrm{a}$. This study reveals a mechanism by which the presence of the TLR2/NOD ligand PG, which is associated with histological markers for plaque vulnerability [11], could influence atherosclerotic plaque development and progression via monocyte recruitment.

L-selectin is constitutively expressed on leukocytes, but is shed by proteolytic cleavage following cellular activation [26]. Indeed, after stimulation for $30 \mathrm{~min}$ by either the PG preparation or $\mathrm{Pam}_{3} \mathrm{Cys}_{-} \mathrm{SK}_{4}$, L-selectin was shed from the monocyte surface. Furthermore, the $\beta_{2^{-}}$ integrin expression on the monocyte surface was increased. These data are consistent with results reported by Sabroe et al. [4], showing decreased L-selectin and increased integrin expression after TLR2 stimulation on neutrophils. In contrast, Saetre et al. [5] showed that Streptococcus pyogenes PG amplified the LTA-induced decrease in expression of L-selectin on monocytes, but that PG stimulation alone had no effect. An important difference with our PG preparation is the bacterial source (S. aureus vs. S. pyogenes), suggesting that the effects of the cell wall components might vary between different bacterial species. Using an in vitro flow chamber model, we analyzed the adhesive behavior of freshly isolated monocytes to E-selectin-expressing and ICAM-1-expressing L cell layers. A limitation of the model used in this study is that these L cells only express E-selectin and ICAM-1 as counterstructures for the monocytes, whereas activated endothelial cells in vivo are known to express a larger array of adhesion molecules, including VCAM-1. It might be very likely that when using a VCAM-1-expressing cell layer, also an increased adhesion would have been observed. Indeed, preliminary data suggested that the PG preparation also increased the $\alpha_{4}$-integrin-dependent monocyte binding to VCAM-1-coated beads. Despite the limitation of only having E-selectin and ICAM1 on the L cells, we think that our results contribute to a better understanding on how TLR2-stimulated mono- cytes might be able to adhere to endothelial cells at sites of inflammation. These L cells have been shown to mediate L-selectin-dependent rolling of neutrophils on E-selectin [24]. We obtained similar results for monocytes and could, therefore, assess the role of L-selectin-dependent/E-selectin-dependent interactions after stimulation. Stimulation of monocytes by the PG preparation or $\mathrm{Pam}_{3} \mathrm{Cys}_{\mathrm{SK}} \mathrm{SK}_{4}$ decreased the total adhesive capacities (rolling plus firm adhesion) to L cells to a similar extent as when L-selectin on monocytes was inhibited. However, a clear difference was observed in the polarization of the cells, since the PG preparation-treated and $\mathrm{Pam}_{3}$ Cys$\mathrm{SK}_{4}$-treated cells all showed a polarized phenotype after 5 min of perfusion, whereas the residual firm adherent cells in the anti-L-selectin-treated group remained rounded. Indeed, we showed that activation of the monocytes by the PG preparation and by $\mathrm{Pam}_{3} \mathrm{Cys}_{\mathrm{S}} \mathrm{SK}_{4}$ resulted not only in an upregulation of $\beta_{2}$-integrin expression as detected by flow cy tometry, but also in a functional increase as detected by the increased binding to ICAM-1-coated fluorescent beads. Interestingly, the PG-preparation-induced and $\mathrm{Pam}_{3} \mathrm{Cys}_{\mathrm{S}} \mathrm{SK}_{4}$-induced activation also resulted in priming of the monocytes, thereby increasing their chemotactic behavior. This effect was TLR2 specific and dependent on $\beta_{2}$-integrins. Previously, Ogawa et al. [27] showed that bacterial cell walls and PG specimens from bacterial walls caused an increase in migration of peripheral blood mononuclear cells towards N-formyl-methionyl-leucyl-phenylalanine. Yipp et al. [28] showed that systemic admission of PG in mice resulted in an increased firm adhesion and migration of total leukocytes as compared with sham-treated mice after $4 \mathrm{~h}$. This at least shows that PG induced similar effects in vivo as we observed in vitro. The increased chemotactic effect upon PG stimulation resembles granulocyte-macrophage-colony-stimulating-factor-induced and IL-5-induced priming of chemotaxis of neutrophils and eosinophils, respectively [29]. It is generally accepted that $\beta_{2}$-integrins play an important role in the migration of monocytes into atherosclerotic sites [6], and, therefore, it might be that PG and $\mathrm{Pam}_{3}$ Cys-SK 4 promote this mechanism.

Dziarski and Gupta [13] suggested that TLR2 is the receptor for isolated S. aureus $\mathrm{PG}$, whereas $\mathrm{Pam}_{3} \mathrm{Cys}_{-} \mathrm{SK}_{4}$ has been shown to bind and signal through TLR2/TLR6 heterodimers. TLR2 recognizes several other molecules as well, including LTA, lipoproteins, and lipoarabinomannan. In a recent study, Travassos et al. [14] concluded that non-PG contaminants of PG preparations (lipoproteins and LTA) are responsible for recognition by TLR2 and that PG detection is more likely to occur through 
NOD2 (CARD15), an intracellular protein. NOD2 is a general sensor for both Gram-positive and Gram-negative bacteria, through the recognition of muramyl dipeptide, the minimal motif found in all PGs [30]. In contrast to NOD2, NOD1 (CARD4) specifically recognizes DAPtype $\mathrm{PG}$ which is present in all Gram-negative bacteria [31]. In this study, we used PG derived from $S$. aureus which does not contain the motif required for NOD1 ligation, but does contain the motif necessary for NOD2 ligation. In addition, our crude PG preparation most likely contains lipopeptides that have potential TLR2-activating capacities, since the isolation procedure was performed as described by Rosenthal and Dziarski [16]. At present, the exact identification of these lipoproteins is under investigation. Theoretically, PG could exert its function via NOD2 activation of monocytes in our study. However, this is unlikely, since we showed that stimulation of the monocytes with the PG preparation and the TLR2 agonist $\mathrm{Pam}_{3}$ Cys-SK $\mathrm{S}_{4}$ resulted in the exact similar effects in all assays that were performed. Furthermore, we showed PG-stimulatory effects on the monocytes after a short incubation time, suggesting that processing of PG into small fragments that are necessary for NOD2 engagement is unlikely. Moreover, the $\mathrm{Pam}_{3} \mathrm{Cys}_{-} \mathrm{SK}_{4}$-induced and PG-preparation-induced priming of migration was abrogated by inhibiting the TLR2 on monocytes.

In previous studies [11], we found that PG was present in atherosclerotic plaques. PG was mainly present in macrophage-rich regions in plaques that displayed all features of rupture-prone vulnerable plaques. Furthermore, we demonstrated that TLR2 is present on vascular cells and that TLR2 ligation by $\mathrm{Pam}_{3} \mathrm{Cys}-\mathrm{SK}_{4}$ is able to induce expression of proinflammatory cytokines and chemokines by vascular cells [10]. Furthermore, using an in vivo mouse model, local adventitial triggering via TLR2 ligation by both $\mathrm{Pam}_{3} \mathrm{Cys}-\mathrm{SK}_{4}$ and the same S. aureus $\mathrm{PG}$ preparation as used here in the arterial wall resulted in increased intimal formation, suggesting an important role for TLR2 in arterial obstruction.

TLR2 has also been shown to bind other bacterial structures like fimbriae from Porphyromonas gingivalis, a microorganism described to accelerate atherosclerosis in an in vivo mouse model [32]. P. gingivalis-derived fimbrial structures induced activation of $\beta_{2}$-integrins determined by the binding of the CBRM1/5 antibody, recognizing the activation epitope of CD11b/CD18 [33]. However, this study did not further address the adhesive and migratory implications of this activation. Furthermore, Chlamydia pneumoniae has also been implicated in the development of atherosclerosis and functionally increased $\beta_{2}$-integrin-mediated adhesion and migration of monocytes and macrophages in vivo [34]. Interestingly, C. pneumoniae activates monocytes via TLR2 [35]. These data support the hypothesis that TLR2-mediated activation of monocytes via PG (our study) or other structures [32] contributes to the development of atherosclerosis.

In this study, we showed a potentially new role for PG preparation in stimulating increased firm adhesion of monocytes to cell layers expressing E-selectin and ICAM1 under flow conditions and increased migratory capacities. The present results suggest that stimulation of TLR2 on monocytes results in activation of the monocytes, thereby increasing the possibility that these monocytes are able to adhere to activated endothelial cells lining the vessel wall at sites of inflammation. Although in vivo this process might be more complex than shown in our model, TLR2 activation might enhance the accumulation of monocytes at sites of inflammation like the atherosclerotic arterial wall.

\section{Acknowledgments}

This work was supported by the Dutch Heart Foundation (grant 2001-077) and the Dutch Foundation for MS Research (grant 04-540 MS). L.H. Ulfman was supported by a grant from The Netherlands Organisation for Scientifc Research (NWO 916.036.051). The authors thank Prof. Ulrich Zähringer for critically reading the manuscript and helpful discussions. 


\section{References}

1 Ross R: Atherosclerosis - an inflammatory disease. N Engl J Med 1999;340:115-126.

-2 Springer TA: Traffic signals for lymphocyte recirculation and leukocyte emigration: the multistep paradigm. Cell 1994;76:301-314.

$\checkmark 3$ Ginsberg MH, Du X, Plow EF: Inside-out integrin signalling. Curr Opin Cell Biol 1992; 4:766-771.

4 Sabroe I, Prince LR, Jones EC, Horsburgh MJ, Foster SJ, Vogel SN, Dower SK, Whyte MK: Selective roles for Toll-like receptor (TLR) 2 and TLR4 in the regulation of neutrophil activation and life span. J Immunol 2003;170:5268-5275.

$\checkmark 5$ Saetre T, Kahler H, Foster SJ, Lyberg T: Peptidoglycan and lipoteichoic acid, components of the streptococcal cell wall, have marked and differential effects on adhesion molecule expression and the production of reactive oxygen species in human whole blood leukocytes. Scand J Clin Lab Invest 2000;60:311-321.

$\checkmark 6$ Huo Y, Ley K: Adhesion molecules and atherogenesis. Acta Physiol Scand 2001;173:3543.

$\checkmark 7$ Medzhitov R, Janeway CA Jr: Innate immunity: the virtues of a nonclonal system of recognition. Cell 1997;91:295-298.

8 Edfeldt K, Swedenborg J, Hansson GK, Yan ZQ: Expression of toll-like receptors in human atherosclerotic lesions: a possible pathway for plaque activation. Circulation 2002; 105:1158-1161.

9 Vink A, Schoneveld AH, van der Meer JJ, van Middelaar BJ, Sluijter JP, Smeets MB, Quax PH, Lim SK, Borst C, Pasterkamp G, de Kleijn DP: In vivo evidence for a role of tolllike receptor 4 in the development of intimal lesions. Circulation 2002;106:1985-1990.

-10 Schoneveld AH, Oude Nijhuis MM, van Middelaar BJ, Laman JD, de Kleijn DP, Pasterkamp G: Toll-like receptor 2 stimulation induces intimal hyperplasia and atherosclerotic lesion development. Cardiovasc Res 2005;66:162-169.

-11 Laman JD, Schoneveld AH, Moll FL, van Meurs M, Pasterkamp G: Significance of peptidoglycan, a proinflammatory bacterial antigen, in atherosclerotic arteries and its association with vulnerable plaques. Am J Cardiol 2002;90:119-123.

$\checkmark 12$ Nijhuis MM, van der Graaf Y, Melief MJ, Schoneveld AH, de Kleijn DP, Laman JD, Pasterkamp G; SMART Study Group: IgM antibody level against proinflammatory bacterial peptidoglycan is inversely correlated with extent of atherosclerotic disease. Atherosclerosis 2004;173:245-251.

13 Dziarski R, Gupta D: Staphylococcus aureus peptidoglycan is a toll-like receptor 2 activator: a reevaluation. Infect Immun 2005;73: 5212-5216
14 Travassos LH, Girardin SE, Philpott DJ, Blanot D, Nahori MA, Werts C, Boneca IG: Tolllike receptor 2-dependent bacterial sensing does not occur via peptidoglycan recognition. EMBO Rep 2004;5:1000-1006.

15 de Jonge BL, Chang YS, Gage D, Tomasz A: Peptidoglycan composition of a highly methicillin-resistantStaphylococcusaureusstrain. The role of penicillin binding protein $2 \mathrm{~A}$. J Biol Chem 1992;267:11248-11254.

16 Rosenthal RS, Dziarski R: Isolation of peptidoglycan and soluble peptidoglycan fragments. Methods Enzymol 1994;235:253285.

17 Müller MR, Pfannes SD, Ayoub M, Hoffmann P, Bessler WG, Mittenbühler K: Immunostimulation by the synthetic lipopeptide P3CSK4: TLR4-independent activation of the ERK1/2 signal transduction pathway in macrophages. Immunology 2001;103:4960.

18 Bracke M, Dubois GR, Bolt K, Bruijnzeel PL, Vaerman JP, Lammers JW, Koenderman L: Differential effects of the $\mathrm{T}$ helper cell type 2-derived cytokines IL- 4 and IL-5 on ligand binding to IgG and IgA receptors expressed by human eosinophils. J Immunol 1997;159: 1459-1465.

19 Gopalan PK, Smith CW, Lu LH, Berg EL, McIntire LV, Simon SI: Neutrophil CD18-dependent arrest on intercellular adhesion molecule 1 (ICAM-1) in shear flow can be activated through L-selectin. J Immunol 1997;158:367-375

20 van Zanten HG, Saelman EU, Schut-Hese KM, Wu YP, Slootweg PJ, Nieuwenhuis HK, de Groot PG, Sixma JJ: Platelet adhesion to collagen type IV under flow conditions. Blood 1996;88:3862-3871.

21 Ulfman LH, Kuijper PH, van der Linden JA, Lammers JW, Zwaginga JJ, Koenderman L: Characterization of eosinophil adhesion to TNF-alpha-activated endothelium under flow conditions: alpha 4 integrins mediate initial attachment, and E-selectin mediates rolling. J Immunol 1999;163:343-350.

22 Geijtenbeek TB, van Kooyk Y, van Vliet SJ, Renes MH, Raymakers RA, Figdor CG: High frequency of adhesion defects in B-lineage acute lymphoblastic leukemia. Blood 1999; 94:754-764.

23 Schweizer RC, Kessel-Welmers BA, Warringa RA, Maikoe T, Raaijmakers JA, Lammers JW, Koenderman L: Mechanisms involved in eosinophil migration. Platelet-activating factor-induced chemotaxis and interleukin5 -induced chemokinesis are mediated by different signals. J Leukoc Biol 1996;59:347356.

24 Abbassi O, Kishimoto TK, McIntire LV, Anderson DC, Smith CW: E-selectin supports neutrophil rolling in vitro under conditions of flow. J Clin Invest 1993;92:2719-2730.
25 Fritz JH, Girardin SE, Fitting C, Werts C, Mengin-Lecreulx D, Caroff M, Cavaillon JM, Philpott DJ, Adib-Conquy M: Synergistic stimulation of human monocytes and dendritic cells by Toll-like receptor 4 and NOD1- and NOD2-activating agonists. Eur J Immunol 2005;35:2459-2470.

26 Blankenberg S, Barbaux S, Tiret L: Adhesion molecules and atherosclerosis. Atherosclerosis 2003;170:191-203.

-27 Ogawa T, Kotani S, Fukuda K, Tsukamoto Y, Mori M, Kusumoto S, Shiba T: Stimulation of migration of human monocytes by bacterial cell walls and muramyl peptides. Infect Immun 1982;38:817-824.

28 Yipp BG, Andonegui G, Howlett CJ, Robbins SM, Hartung T, Ho M, Kubes P: Profound differences in leukocyte-endothelial cell responses to lipopolysaccharide versus lipoteichoic acid. J Immunol 2002;168:4650-4658.

29 Warringa RA, Mengelers HJ, Kuijper PH, Raaijmakers JA, Bruijnzeel PL, Koenderman $\mathrm{L}$ : In vivo priming of platelet-activating factor-induced eosinophil chemotaxis in allergic asthmatic individuals. Blood 1992;79: 1836-1841.

30 Girardin SE, Boneca IG, Viala J, Chamaillard M, Labigne A, Thomas G, Philpott DJ, Sansonetti PJ: Nod2 is a general sensor of peptidoglycan through muramyl dipeptide (MDP) detection. J Biol Chem 2003;278: 8869-8872.

31 Girardin SE, Boneca IG, Carneiro LA, Antignac A, Jehanno M, Viala J, Tedin K, Taha MK, Labigne A, Zähringer U, Coyle AJ, DiStefano PS, Bertin J, Sansonetti PJ, Philpott DJ: Nod 1 detects a unique muropeptide from Gram-negative bacterial peptidoglycan. Science 2003;300:1584-1587.

32 Gibson FC 3rd, Hong C, Chou HH, Yumoto $\mathrm{H}$, Chen J, Lien E, Wong J, Genco CA: Innate immune recognition of invasive bacteria accelerates atherosclerosis in apolipoprotein E-deficient mice. Circulation 2004;109: 2801-2806

>33 Harokopakis E, Hajishengallis G: Integrin activation by bacterial fimbriae through a pathway involving CD14, Toll-like receptor 2, and phosphatidylinositol-3-kinase. Eur J Immunol 2005;35:1201-1210.

34 May AE, Redecke V, Gruner S, Schmidt R, Massberg S, Miethke T, Ryba B, Prazeres da Costa C, Schomig A, Neumann FJ: Recruitment of Chlamydia pneumoniae-infected macrophages to the carotid artery wall in noninfected, nonatherosclerotic mice. Arterioscler Thromb Vasc Biol 2003;23:789-794.

35 Netea MG, Kullberg BJ, Galama JM, Stalenhoef AF, Dinarello CA, Van der Meer JW: Non-LPS components of Chlamydia pneumoniae stimulate cytokine production through Toll-like receptor 2-dependent pathways. Eur J Immunol 2002;32:11881195. 